\title{
A vítima enunciada: Experiências da dor comum em relatos-postagens do Facebook ${ }^{1}$
} The enunciated victim:
experiences of a common pain on Facebook posts

Angie Biondi | Universidade Tuiuti do Paraná Professora do Programa de Pós-Graduação em Comunicação e Linguagens da Universidade Tuiuti do Paraná.

Doutora em Comunicação Social pela UFMG

E-mail: angiebiondina@gmail.com

\section{Resumo}

Este texto busca investigar as mudanças qualitativas que ocorrem no estatuto da vítima e na forma de enunciação da dor vivida cotidianamente e compartilhada através dos breves relatos-postagens que circulam nas redes sociais. $\mathrm{O}$ esforço de análise privilegia as materialidades linguageiras de alguns casos exemplares recentes veiculados no Facebook. Acreditamos que esta reflexão soma-se aos esforços de uma compreensão crítica acerca das formas com as quais a sociedade lida com a dor do outro e como tem se servido destas ferramentas de produção e compartilhamento instantâneos que integram enunciação e visibilidade contemporâneas.

Palavras-Chave: Redes sociais; Experiência; Vítima.

\begin{abstract}
This paper examins qualitatives changes in the victim's status and in the form of the pain enunciated by people that lives daily has been shared through reports and postings that circulates on social networks. The analysis effort privileges the materialities of everyday language in some recente copies cases on Facebook. We believe in what this reflection could sum up the effort of a critical understanding in the ways society deals with another's pain and how has served these snapshots production and sharing tools that integrate contemporary enunciation and visibility forms.
\end{abstract}

Keywords: Social networks; Experience; Victim. 


\section{Introdução}

As vivências ordinárias dos sujeitos comuns têm ocupado um lugar de destaque nas chamadas redes sociais e nutrido polêmicas e debates de todo tipo que, frequentemente, extrapolam as páginas pessoais nas quais são postadas ampliando seu espaço enunciativo. Em muitos casos, é a própria mídia que reproduz tais exemplares no afă de pautas cada vez mais renovadas na busca por audiência.

No caso mais recente, pudemos observar como a hashtag \#primeiroassédio, criado pelo Coletivo ThinkOlga, para denunciar as manifestaçóes de abuso contra uma participante de 12 anos, em um programa de TV, adquiriu relevância com a adesão instantânea de inúmeras mulheres que, incentivadas pela campanha, partilharam suas experiências de dor, vergonha e medo através do Twitter. Os breves relatos se espraiaram rapidamente pelos retweets de apoio e compartilhamento, além de terem se tornado pauta em outros tantos programas televisivos, na imprensa e portais de notícias das últimas semanas.

Temos observado que uma profusão de causas individuais no Facebook, Instagram, blogs e fotologs são multiplicadas pelos meios de comunicação tradicionais. São causas que se declaram legítimas e justificáveis em tempos de uma precária e insuficiente participação do Estado e que se caracterizam pela enunciação dos próprios sofredores. Para isso tem sido comum particularizar os sofrimentos, lhe atribuir um rosto e uma consistência individual, embasar, na própria vida, a dor que lhe consome cotidianamente. Notamos que ao repertório de protesto e denúncia como instrumentos privilegiados da visibilidade social às mazelas da vida cotidiana, desde o período moderno, prevaleceriam agora novos apelos à chamada "sensibilidade humanitária" ou "pós-humanitária" (CHOULIARAKI, 2013), postos diretamente à cada sujeito conectado. Ambas, porém, são formas produtoras e instituintes de uma subjetividade específica que confere um estatuto peculiar à vítima e modula as formas de suas interaçôes nas quais as vivências cotidianas da dor e sofrimento têm sido partilhadas.

Um modo peculiar de vítima se mostra, então, aninhado nestes breves gestos enunciativos que pululam nas redes sociais e que, por mais que se diferenciem, em boa medida, dos discursos jornalístico, religioso ou político-partidário - por se declararem autênticos e legítimos - podem ainda articulá-los criativamente a fim de convocar formas de adesão a suas histórias e causas passando por variados campos de afinidade e interaçôes afetivas. Nos interessa investigar quais são estas possíveis mudanças qualitativas que ocorrem, tanto no estatuto da vítima quanto na forma de enunciação de suas vivências cotidianas da dor ${ }^{2}$, através destes relatos-postagens que são compartilhados pelas redes sociais hoje.

Ao invés de estabelecer, como ponto de partida, um estudo dos textos e produtos midiáticos estrategicamente construídos como os exemplares privilegiados através dos quais se refletiriam os fluxos da vida social, adotamos uma perspectiva contrária aos inúmeros discursos midiáticos que sempre abarcaram os falares e as vivências cotidianas dos sujeitos. "Lançamo-nos na investigação desse universo de pequenas falas, de imagens sintetizadoras, de ruídos que nos dizem do movimento de uma sociedade que, ao falar, se constitui cotidianamente" (GUIMARÁES, 2006, 8). 
Como afirmou Certeau (1998), os homens comuns, com suas vidas ordinárias e cenas reais, sempre foram ditos pelas "línguas artificiais dos peritos e especialistas”. Percorremos, então, um caminho contrário. Concentramos esforços para tentar compreender a relação entre o vivido e o narrado das vítimas do cotidiano (DAS, 2007).

Assumir o estudo dos traços da experiência da vida ordinária encarnados nas materialidades narrativas linguageiras, portanto, nos solicita uma postura epistemológica. Deste modo, buscamos observar a sociedade através de suas próprias falas que integram, interagem, desconstroem, multiplicam, apropriam, enfim, que constituem a "vida de todos os dias" e que nos permite entrever as dinâmicas envolvidas na experiência narrativizada (GUIMARÁES; FRANÇA, 2006) e partilhada da dor.

Acreditamos que esta reflexáo soma aos esforços de uma compreensão crítica acerca das formas com as quais a sociedade lida com a dor do outro e como tem se servido destas ferramentas, ditas sociais, de produção e compartilhamento instantâneo, que integram, simultaneamente, formas de enunciação e visibilidade das experiências de dor vividas e partilhadas. Uma observação destes entrecruzamentos, não poderia se restringir aos relatos das vítimas apenas, mas associar tais gestos enunciativos, ainda que breves, às formas de compartilhamento e suas maneiras de interpelação e aderências.

\section{A vítima nos deslocamentos de uma enunciação}

Relatos diários de doenças, autorretratos (selfies) em acidentes, violências sofridas e agravos de toda sorte têm se proliferado nas redes sociais. Ao se apropriarem destes recursos tecnológicos, já bastante naturalizados no dia-a-dia, cada sujeito é tâo responsável quanto autônomo pela apresentaçáo de suas vivências ordinárias.

Uma diversidade de situaçóes prosaicas é exibida de modo a constituir uma espécie de cartografia das trajetórias individuais onde é possível observar as diferentes exploraçóes temáticas que sustentam e renovam o interesse pelas vidas e sofrimentos reais. O sujeito comum parece ter encontrado, nas redes sociais, um espaço propício para declarar a verdade de suas mazelas, bem como para agregar, em torno de si, um conjunto de seguidores e fazer de sua luta, muitas vezes, uma causa legítima a se engajar, aderir, compartilhar, enfim, se solidarizar de algum modo.

Nas circunstâncias em que dores e sofrimentos são o mote principal da exposição, os sujeitos partilham do mesmo espaço de visibilidade, e também de construção de narrativas, sobre a própria vida onde a voz principal é a da vítima, pois é ela quem encarna a legítima instância moral e política. Sem qualquer outro mediador instituído e erigindo para si a posição legítima do sujeito de fala, anônimos de todas as partes do mundo assumem a autoria qualificada das diversas mazelas de suas vidas reais. Nesta composição de vozes anônimas e legítimas pelo menos dois aspectos se destacam: a) o modo como se apresentam estes sujeitos que ocupam a posição consciente e qualificada de vítima; b) a forma que modula a exposiçáo desta vitimização, agora criada na lógica do conexionismo, ou seja, feita para conectar e compartilhar. 
Quais significados adquire a vítima dentro deste contexto? Tem-se aqui uma construção de fala do sujeito que, consciente de seu lugar e da projeçáo que pode alcançar, se pôe como agente qualificado das dores reais e legítimas, isto é, como autêntico portador de uma experiência originária capaz de mostrar a verdade das coisas que merece ser compartilhada.

"A construção da pessoa como vítima no mundo contemporâneo é pensada como uma forma de conferir reconhecimento social ao sofrimento, circunscrevendo-o e dando-lhe inteligibilidade" (SARTI, 2011, 54). Neste contexto, compartilhar se torna uma ação complementar e extensiva à situação em que se encontra o sujeito que vive e narra ao mesmo tempo.

Vale ressaltar que identificar a vítima e qualifica-la, inclusive, juridicamente, no âmbito de uma democracia política sempre fez parte dos anseios da sociedade ocidental moderna (SARTI, 2011), que esboçava sistemas de regulação e responsabilização social pelo sofrimento das populaçóes. O estatuto da vítima se delineou, neste processo, segundo Sarti (2011), viabilizado pela necessidade de reconhecimento de alguns dos maiores episódios históricos de violência mundial como o holocausto nazista e as ditaduras militares.

A vítima comparece, portanto, investida por um sistema político e normativo criado como critério social que fundamenta a condição de notória vulnerabilidade do sujeito. Se tornar uma vítima é, sobretudo, uma operação de visibilidade em que o reconhecimento se institui normativamente. Até então, não cabia ao sujeito se intitular vulnerável e assim se declarar na posição de vítima, mas receber e acatar uma qualificação que lhe é normativamente e institucionalmente atribuída. Os discursos que se produziram em torno da vítima se proliferaram de tal modo a conceder-lhe um status de categoria social que se universaliza.

Segundo François Laruelle (2015), o trabalho dos especialistas, filósofos e intelectuais da moral do século XX acabou construindo uma voz às vítimas domando e aprimorando sua experiência em um processo de teorização intelectual e política. Para o autor, seria necessário ouvir a vítima para abrir uma possibilidade de conhecimento do seu lugar e de sua voz que náo poderiam jamais ser teorizados sob conceitos representativos. A dupla ameaça à vítima é isolá-la em um termo e subjuga-la aos rituais de memória (LARUELLE, 2015, 67).

De todo modo, o entendimento da vítima precisava perpassar um contexto para seu necessário reconhecimento e posterior designação.

Categoria histórica, seu significado define-se contextualmente, na dinâmica dos deslocamentos de lugares que marca as relaçôes intersubjetivas, situadas em estruturas sociais de poder no interior das quais os conflitos sáo negociados. Trata-se de reconhecer os mecanismos sociais e políticos de reconhecimento e nomeação da violência pelos quais a pessoa, na acepçâo de Mauss (1974b), é construida como vitima, a gramática moral que lhe dá sustentação e, no plano do sujeito, a percepção subjetiva de si mesmo como tal. (SARTI, 2011, 54).

Sem uma proposição determinada, mas no intuito de estabelecer um aspecto comparativo e diferenciado do estatuto da vítima moderna como explicado, nos casos exemplares que observamos, preliminarmente, nesta pesquisa, 
o movimento que se insinua é justamente o contrário. A vítima é que se autodeclara, se enuncia, para instituir, a partir de si, uma legitimidade sobre sua condição de vulnerabilidade.

Não observamos, até então, um aspecto externo de atribuição normativa como critério definidor de sua condição de vítima, mas uma força declarativa própria que maneja um estatuto que lhe é pressuposto com base na vivência anunciada das circunstâncias de dor e sofrimento que são compartilhadas em público. Se no período moderno o sujeito era aquele nomeado vítima, atualmente, ele não parece considerar válida uma designação institucional prévia, posto que a experiência in loco se sustenta como critério de base para a enunciação (e exibição) de sua condição e afirmação de seu status.

Nestes breves enunciados sobressaem experiências da fragilidade, do desamparo e da dor vividas cotidianamente. Em boa medida, ponderamos se é possível emergir - e de que modo - uma nova gramática moral da vítima, a partir destas formas da autodeclaração e da partilha.

\section{Sobre alguns relatos-postagens de vítimas no Facebook: pistas para uma compreensão dos gestos}

Em junho de 2014, a campanha Amigos do Pedrinho, foi criada nas redes sociais pela mãe do bebê, Aline Bagarão. No dia 16 de maio de 2015, a página divulgou que uma arrecadação em dinheiro, em pouco mais de um mês, já tinha atingido o valor de $\mathrm{R} \$ 964$ mil. Ainda era preciso chegar ao montante de R \$2 milhões para realizar, nos Estados Unidos, o transplante de intestino que salvaria a vida do garoto, que nasceu com uma síndrome rara no órgão.

A página criada para a campanha, até então, já contava com 124 mil compartilhamentos. Além disso, celebridades e famosos se engajaram e também replicaram e curtiram a página. Em Marília, cidade natal do garoto, outras açôes se somaram ao esforço familiar de arrecadar fundos e divulgar a causa. Um pedágio foi realizado pelos moradores em uma das principais vias da cidade e, em pouco mais de três horas, obteve $\mathrm{R} \$ 7$ mil. O valor arrecadado foi entregue aos pais do menino.

A iniciativa da mãe de Pedrinho prosseguiu e ganhou mais adeptos ao longo do ano. Outras ações foram promovidas a fim de arrecadar o montante necessário para o transplante. Rifas, bazar, material promocional com o slogan "I love Pedro" foram comercializados, foi publicado um livro intitulado "Biografia em branco do Pedrinho" e também um site "Amigos do Pedrinho", para auxiliar na divulgação da campanha e fornecer informaçôes dos dados bancários para doaçôes. Entretanto, sua página no Facebook, "Ajude o Pedrinho a continuar sorrindo", até o momento desta escrita, com 337.572 curtidas, que antes funcionava como um diário exclusivo do dia-a-dia do Pedrinho, ganhou uma proporçáo maior com a divulgação de outros casos de crianças com síndromes e doenças raras que precisam de tratamento e cirurgias especiais. Em 16 de dezembro de 2014, Ajude o Pedrinho... se aliou a outras páginas semelhantes e formaram a atual comunidade Clique da Esperança. 
Além do Pedrinho, Davi Miguel, Ana Júlia, Sofia, Yasmim, Nicolly, Flávia, Nicolas e outras tantas crianças se juntam, todos os dias, à comunidade, com suas páginas do Facebook e, em geral, através dos seus pais, divulgam sua rotina de tratamento doloroso, mas também de esperança e luta. É comum encontrar nas páginas diárias os detalhes dos sintomas, o uso de novas medicaçôes, o dia de exames, as recaídas e também os momentos de superação, as brincadeiras, os presentes, cartinhas e mensagens de amigos, parentes e desconhecidos que chegam, solidários, aos seus leitos.

Na história de vida do Pedrinho, em 13 de novembro de 2014, ele chegou a Miami e, a partir daí seus relatos foram intensificados no intuito de prestar explicaçôes sobre cada momento do tratamento pré-operatório do garoto. A resposta dos seguidores é imediata. A cada registro ou pequena descrição do seu dia, milhares de curtidas e compartilhamentos são realizados. As fotografias e vídeos onde ele aparece tomando sopinha, dormindo, mas também com febre, sedado, entre tantas situaçôes do seu sofrimento, são sempre descritas como etapas a serem vencidas, batalhas a serem conquistadas e fraquezas a serem superadas com a ajuda e oração das pessoas que acompanham sua história diária. A mãe Aline, também a narradora, descreve o dia-a-dia de Pedrinho sempre agradecendo e convidando a refletir sobre o papel de importância em se manter próximos e solidários de algum modo.

"Nosso príncipe", "nosso guerreiro", "nosso menino", como frequentemente se refere a mãe do garoto, invoca a união e solidariedade dos seguidores - a esta altura, já participantes, inscritos na história - junto às descriçôes acompanhadas com fotos e vídeos do tratamento e do transcorrer do dia. Suas mensagens são deixadas como demonstrações de uma manutenção deste espírito coletivo. "Nosso" é um indicador linguístico exemplar do pertencimento comum.

Segundo VAZ; RONY (2008), os sujeitos desde cedo souberam partilhar da estreita relação entre emoçôes e crenças. A compaixão, a indignação e a solidariedade são todas manifestaçôes tributárias destes jogos de fala, dos lugares e das estruturas sociais por onde circulam o poder. Compaixão ou indignação são emoçôes de observadores, por isso, tão sociais quanto socializantes (VAZ; RONY, 2008, 22). E é sobre observadores e espectadores, que os movimentos de uma moral aliada às emoçôes ainda são postos em cena ao tematizar a vítima. A compaixão, a indignação, mas também a solidariedade, sempre refletiram as balizas morais nas quais estão distribuídas as posiçôes entre os agentes no processo de visibilidade e também de enunciação, entre o sofredor e o espectador.

A mãe Aline, muitas vezes, assume o lugar de fala do próprio Pedrinho. É comum despedir-se "com fé", "paz no coração", beijinhos do Pedrinho", "obrigada, Pedrinho". Não raro, a mãe alterna os papeis e, ao mesmo tempo em que assume a identidade da narradora e companheira fiel do pequeno sofredor, também descreve sensaçôes e desejos como se fosse o próprio garoto em votos de agradecimento e união a todos aqueles que acompanham e participam de sua luta. Segundo Boltanski (1999), certa organização narrativa do "nós" se mantém sob o princípio da retórica quando se apresenta coligada aos modos de interação centrados na observação à distância. Toda composição narrativa 
dos sofrimentos, no período moderno, era modelada para elaborar a denúncia anódina das mazelas sociais. Reconhecer, apenas, a condição vulnerável do outro não assegurava qualquer indicativo à ação direta, mas táo somente circunscrevia um lugar ao espectador que, distante, pactuava daquela realidade. "A disjunção entre as possibilidades de informação e as possibilidades de ação pôs sobre o espectador a incerteza crescente sobre qual ação seria necessária" (BOLTANSKI, 1999, 16).

Nas escritas dos relatos-postagens, no entanto, o apelo é vocativo e testemunhal. A escrita adquire um tom de conversação oral, mais fluida e com menos preocupação formal ou estilística, pois escreve como se falasse diretamente a alguém. Há uma relação complexa e dinâmica entre o si e o outro esboçada aqui. Os relatos-postagens oscilam entre a prática do registro que solicita a convocação do outro para ver e compartilhar sua experiência, mas também sublinham a reivindicação moral colocada pela partilha da dor e sofrimento de quem interpela e pede ajuda ao outro. Parece haver um desejo quase incontrolável de quem quer contar, ao outro, o que se sente, no intuito de tornar o outro não um mero espectador à distância ou um seguidor passivo, mas um efetivo participante da história; sua testemunha.

Vale destacar que a escrita que se esboça nestas pequenas autobiografias ${ }^{3}$ da dor cotidiana partilhadas em rede nem sempre é retrospectiva, e em prosa, mas ocorre no calor da hora; no momento mesmo do acontecimento. Aliás, o sentido do compartilhamento parece ter maior legitimidade (e ser mais valorizado) se for postado no momento em que ocorre. Deste modo, se estabelece uma espécie de compromisso tácito entre o sujeito narrador e seus participantes.

Em outro caso exemplar, Gabe Kowalczyk, um jovem de 19 anos, usou sua página nas redes sociais para denunciar a violência sofrida minutos antes. Gabe tinha acabado de ser agredido na rua. Ao sair de casa, em direção ao ponto de ônibus, três homens o abordaram por conta de sua aparência feminina.

Em sua página: "Desci umas duas ruas para baixo da minha casa em direção ao ponto de ônibus. Não tinha andado nem 300 metros quando percebi que tinha três caras andando atrás de mim. Quando vi continuei de cabeça baixa e apertei o passo para chegar o mais rápido possivel até a Miguel Yunes, uma avenida movimentada onde eu poderia correr para algum lugar. Estava a 10 metros da avenida quando eles chutaram a minha perna e me derrubaram. Cai de cara no chão, ralou tudo. Tenho um piercing no nariz e ele enroscou em algum lugar e me machucou muito. Tentei me virar e um cara mais gordinho virou meu corpo e os três começaram me dar chutes e socos, enquanto falavam: 'Sua bicha, seu ridiculo, quer ser mulher entäo vai apanhar que nem mulher'. Meu corpo estava tão machucado que eu tentava gritar e só saíam gemidos."

O relato de Gabe se prolonga e ele conta detalhes da violência, da tentativa de estupro, do registro policial, da volta para casa, da reaçáo dos pais, ao mesmo tempo que declara sua angústia, preocupaçáo, medo e apelo às pessoas contra a violência homofóbica. Como ele mesmo declara no título de sua postagem: "virei estatística. De novo". Além de relatar a violência, Gabe também postou várias selfies dos ferimentos. Sua postagem repercutiu pelas redes e foi compartilhada por milhares de usuários. Logo a mídia também se valeu do caso do jovem e divulgou sua própria postagem em revistas, jornais, portais de notícias e programas de TV. 
A observação acerca das formas autobiográficas, de narrativas do eu ou escritas de si, não constitui uma novidade às investigaçóes em torno do sujeito que narra, nem mesmo em torno dos estudos dos gêneros narrativos e literários, embora em muito nos forneça um manancial de discussóes fundamentais sobre seus aspectos. Porém, o que traz essas breves formas narrativas ao centro das discussões hoje é a inegável existência de certa força mobilizadora - tão afetiva quanto real, que se constitui a partir da conjunção das narrativas pessoais com os dispositivos tecnológicos de comunicação instantânea que produzem, armazenam, compartilham e conectam em torno de certas situações vivenciadas, antes tão intoleráveis quanto invisíveis no espaço público.

Nas narrativas, o tempo destrói e desestabiliza relaçóes, mas também, repara e reconstrói o presente ao refazer o fluxo da vida (DAS, 2007, 41). Advêm desta articulação as variaçóes e deslocamentos significativos dos agentes imiscuídos no processo narrativo que mobiliza, simultaneamente, as instâncias da enunciação, visibilidade, mas também da mediação e compartilhamento, em um arranjo íntimo e peculiar.

Esta reciprocidade, de parte a parte, explica, em primeiro lugar, que esta experiência narrativizada está desvinculada de uma posição hierarquicamente privilegiada, mas perpassa os diferentes domínios do cotidiano; em segundo lugar, que sua potencialidade se torna eminente em um campo de acionamento que se conjuga entre sujeitos em relação. Portanto, é situada, contextualizada por materiais expressivos que, em arranjo, tensionam, de diferentes modos, a relação sujeito/objeto produzindo deslocamentos interativos e afetivos. Com efeito, a experiência estética e subjetiva, "nem se deixa apreender simplesmente como uma modalidade particular da experiência comunicacional em geral, nem tem justificada sua dimensão estética simplesmente porque os objetos e as situaçóes presentes nas trocas comunicativas acionam componentes de natureza sensível” (LEAL; GUIMARÃES; MENDONÇA, 2010, 8).

A vítima/narrador/sofredor não se investe como outro personagem, mas como sujeito real e autêntico que não mascara ou elabora um modelo prévio de si, mas se apresenta como supostamente é em sua vida real, em situaçóes reais de dor e sofrimento. $\mathrm{O}$ já clássico debate empreendido em torno dos estudos sobre estas formas narrativas do eu por dois de seus maiores pesquisadores, Philippe Lejeune $(1971 ; 2008)$ e Serge Doubrovsky $(1977 ; 2014)^{4}$, permite aqui retomar o conceito de autoficção como expressão mais adequada ao problema de nosso interesse.

Autoficção, segundo Doubrovsky (2014), para além de designar as diversas formas das escritas íntimas, compondo um gênero narrativo onde se contemplam as cartas, os diários, correspondências, ensaios, confissóes, memórias e todo tipo de relato em primeira pessoa, se caracteriza, em primeiro lugar, pelo hibridismo das categorias real e ficcional, que abala tanto os valores de verdade e legitimação, outrora requeridos, quanto a validade da instância de enunciação. Em segundo lugar, o termo recoloca o autor não como simples instância de controle da narrativa, mas como sujeito que performa, no processo mesmo de sua prática - de seus escritos dos relatos-postagens, a própria imagem de si. 
Este último aspecto, principalmente, nos parece caro no trabalho de investigar como as interaçóes entre sujeitos, suas trocas, efetuaçóes e contra-efetuações de posiçóes e papeis (enunciador/autor/espectador/personagem), conformam e configuram um processo fluido e ativo da experiência narrativizada. As próprias escritas indicam a imprecisão dos lugares marcados pela relação conflituosa da experiência de uma violência, por exemplo, e a subjetividade no "delicado trabalho de auto-criação", da negociação subjetiva dos sujeitos e sua reconstrução possível no mundo social e interativo (DAS, 2011, 18).

Assim, ao mesmo tempo, esta suposta apresentação direta da "vida como ela é” reforça a noção de participação dos seguidores em cada história de vida pessoal a que se juntam ou causa a que aderem, mesmo momentaneamente. Ao insistir neste caráter íntimo que configuram todas estas formas de relatos-postagens não partimos do pressuposto de que haja um mascaramento do sujeito determinado pelos "repertórios banalizados que circulam midiaticamente" (JAGUARIBE, 2006, 111) e que viriam envolver os sujeitos em uma espécie de modelo identitário e generalizado que classifica seus relatos. Estes pequenos relatos íntimos disseminados em redes, mesmo breves, se qualificam pelo teor testemunhal que apresentam. Lembramos que tomar um testemunho significa, sobretudo, indicar uma dimensão de confiança mútua, de cumplicidade entre os sujeitos envolvidos na situação narrativa.

Se a individualidade privada assumiu, nas redes, um lugar de destaque, não foi pela construçáo de um personagem como recurso central e distante dado pelas narrativas típicas de um herói, nem pela maestria artístico-literária do seus escritores narradores, mas pela contínua apresentação de dores e sofrimentos cotidianos que os expóem em suas fragilidades, opacidades, lacunas, silenciamentos, fraquezas, dúvidas, hesitaçóes e mesmo pelos interstícios que compóem as precárias escritas de si circunstanciadas pelas vivências que movimentam as intensidades dos laços afetivos que promovem com aqueles que os seguem, compartilham, curtem, repostam.

É sinal dos tempos, entretanto, que enquanto o século XIX foi prodigioso em biografias e autobiografias de personagens notáveis, o século XX alargou, consideravelmente, a galeria de personagens passiviveis de ingressarem no âmbito do espaço biográfico e diversificou o gênero canônico da autobiografia exemplar numa pluralidade de relatos intimos, confessionais e revelatórios (JAGUARIBE, 2006, 115).

Percebemos que aqui há uma série de deslocamentos e reformulaçôes que tanto colocam em xeque a caracterização dos agentes da situação narrativa (deslocados do modelo dual sofredor-espectador, objeto-sujeito) quanto trazem à tona um conjunto de desdobramentos e implicações estéticas, morais e políticas que reformulam os quadros da sociabilidade e subjetividade atuais das vítimas e de como as conhecíamos, outrora enquadradas e classificadas pelo jornalismo, pelo discurso religioso ou mesmo político partidário. A vocação documentária de todos estes relatos-postagens, em seus microdiários, nas redes, agencia, antes de tudo, um valor de mobilização, pois atua nas intensidades afetivas e nos laços empáticos que a experiência da dor narrativizada potencialmente articula. 


\section{A dor comum: da demanda coletiva ao engajamento afetivo}

Vimos que o discurso da "comum humanidade" (BOLTANSKI, 1999) que vinculava sofredor e espectador na base de uma moralidade piedosa caducou frente às solicitaçóes de uma sociedade tecnológica, multicultural e pluralista. A assimetria inerente às posições de quem vê e de quem sofre, tão criticadas na "política da piedade" (BOLTANSKI, 1999; ARENDT, 2001), foi substituída pela liberdade de escolha garantida por uma política, nomeada de democrática e liberal, que não se furta em ser um componente ativo desta reformulação dos lugares e dos pactos entre o que vê e o que sofre.

Se o espectador se encontra livre do imperativo moral que o constrangia aos revezes sentimentais modernos, hoje, no entanto, ele se encontra enredado por um tipo de comunicação que não é previamente organizada e endereçada a uma coletividade pré-existente de espectadores passivos e bem informados sobre as mazelas do mundo, mas constitui um corpo coletivo de ação no processo mesmo de visualização e enunciação das contingências (CHOULIARAKI, 2010, 111).

Segundo Boltanski e Chiapello (2013), desde meados de 1980, houve um recrudescimento da miséria mundial causado pelo intenso desenvolvimento unilateral de algumas sociedades. Entretanto, este mesmo período apresentou um processo de desqualificação e descrédito das instâncias críticas que haviam predominado nas duas décadas anteriores. Diante desta fragilidade e da ausência de uma teoria argumentativa que possibilitasse fundamentar a revolta na razáo, a preocupação social e os movimentos de militância política (decepcionados com a ineficácia das organizaçôes sindicais e as manobras políticas das instituições) que a acompanharam passaram a adotar a forma da ação humanitária criando novas formas de associaçooes (BOLTANSKI; CHIAPELLO, 2013, 357). Em boa medida, este movimento significou uma atualização das açôes humanitárias em sua proposta de engajamento e ajuda direta às vítimas prescindindo de uma cadeia de intermediários e representantes.

O "novo espírito do capitalismo" ao invés de buscar a normatização e a disciplina que regularam a modernidade passou a reconhecer, valorizar e, sobretudo, assimilar as formas flexíveis da experiência, a força de produçáo de singularidades, a inventividade, a formação de teias comuns e a criação de si com o outro. Houve não apenas a formulação de uma "nova gramática mínima do elo" mas uma renovada "política do conexionismo" (BOLTANSKI; CHIAPELLO, 2013, 175). A noção de rede respalda, segundo os autores, outra representação de mundo sustentada pela intersecção entre o discurso da gestão empresarial (impulsionado nos anos 80) e o discurso das ciências sociais.

Assim, por exemplo, as qualidades que, nesse novo espirito, são penhores de sucesso - autonomia, espontaneidade, mobilidade, capacidade rizomática, polivalência (em oposição à especialização estrita da antiga divisão do trabalho), comunicabilidade, abertura para os outros e para as novidades, disponibilidade, criatividade, intuição visionária, sensibilidade para as diferenças, capacidade de dar atenção à vivência alheia, aceitação de múltiplas experiências, atração pelo informal e busca de contatos interpessoais - são diretamente extraídas do repertório de maio de 68 (BOLTANSKI; CHIAPELLO, 2013, 130).. 
Deste modo, a nova conformação política e social de um capitalismo flexível alterou a formatação dos agentes, mas não provocou profundas modificaçóes estruturais. Seguindo esta perspectiva, o modelo representativo do sujeito-objeto, lido nas figuras do sofredor-espectador, se mantém estruturalmente apesar de terem renovadas as formas de enunciação e visibilidade dos seus agentes e os modos de acesso às mazelas da vida ordinária; agora moduladas em rede, de modo direto e, supostamente, sem mediadores. Daí convocar-se, diretamente, cada sujeito conectado, seja para se solidarizar com a luta pela sobrevivência do Pedrinho ou para se juntar ao apelo de "não homofobia” de Gabe.

Na perspectiva moderna, o "nós" e o "outro" eram os agentes que se enredavam em uma trama baseada no esquema representativo antagônico do sujeito-objeto. A diferença atual, sublinhada por uma pesquisadora como Chouliaraki (2011; 2013), é que à declaraçáo da falência pessoal do espectador diante da dor e sofrimento inalcançável do outro, se póe agora um jogo simultâneo de singularidades. De um lado, o espectador-participante, de outro, o agente vitimado, sofredor-narrador, que pressupóe uma autonomia - antes negada pelo silêncio resignado do preconceito e da discriminação que lhe impunha a vergonha como censura moral - agora flexibilizada pela possibilidade (ou imperativo) da autoprojeção.

De certo modo, mesmo que pelo mínimo gesto, as pessoas são provocadas a responder também afetivamente e, por isso, se multiplicam a cada clique. Os movimentos de enunciação, visibilidade, mas também de adesão e engajamento são facilitados, de modo mais prático e instantâneo, pelas ferramentas tecnológicas que atuam em rede e que valorizam a auto-exposiçáo como fator que serve à atualização ou renovação de suas histórias e causas cotidianas. São estas as vítimas que têm ocupado o lugar de fala e se tornado tanto triviais quanto legítimas no horizonte de visibilidade contemporâneo.

Há uma disputa política no/pelo simbólico que se trava entre o espaço da intimidade -calcado na necessidade de expor dores e sofrimentos cotidianos atrelados aos revezes de fragilidade e força de superação que se constitui narrativamente-, e a exterioridade da palavra consciente de que o outro náo poderia jamais vivenciar a mesma dor e angústia. $\mathrm{O}$ sofrimento vivido e narrado, que busca convocar formas de adesão e interaçóes afetivas, não pode ser pensado tendo como única referência a realidade dos fatos, mas a forma com a qual esta experiência é partilhada.

Como abertura, uma experiência vivida e narrativizada permite notar que sua efetivação se dá em um contexto concreto de "ação e comunicação em que o sujeito é levado a desenvolver uma compreensão pragmático-performativa do objeto que lhe é apresentado" (GUIMARÃES, 2004, 3). É, então, inserido neste contexto ativo de constrangimentos e de aberturas que os sujeitos aparecem implicados em um conjunto de orientaçóes volitivas, cognitivas e afetivas.

Os constantes deslocamentos provocados por tais orientaçôes, em dada situação, incidem nos seus quadros comuns e familiares marcando alteraçôes em suas referências e trazendo outras negociaçóes com as narrativas partilhadas. Para que uma dor vivenciada seja partilhada a fim de mobilizar algum tipo de adesão é necessário que haja algum mínimo grau de empatia. A dor e o sofrimento não se 
concretizam como um fato ou uma ocorrência banal apenas, mas se constituem através de uma forma pela qual só podem ser "apreendidos" pelos sujeitos através de uma relação com os vestígios de suas vivências e com seus traços, ainda que precários, que podem ser notados no percurso destas breves narrativas partilhadas.

\section{Considerações finais}

Como vimos, as dores e os sofrimentos vivenciados cotidianamente pelos sujeitos assumem uma forma narrativizada da experiência que é produzida e partilhada em redes. Uma observação preliminar destes relatos-postagens que circulam no domínio do Facebook, por exemplo, nos permitiu indicar um conjunto inicial de questóes acerca do processo complexo entre visibilidade e enunciação em jogo. Se antes o sujeito que vivenciava uma dor ou sofrimento precisava ser inscrito em uma condição de vulnerabilidade através de uma designação normativa e exterior, legitimado pelos discursos conferidos pelas instâncias políticas, religiosas ou ainda midiáticas, agora ele mesmo antecipa sua condição vulnerável e se enuncia como vítima.

Ademais, esta reconfiguração dos lugares de fala da vítima adensa os modos de adesão e interaçóes propriamente afetivas com os seguidores postos na situação narrativa. Além de sublinharem a responsabilidade pela tomada da palavra que os sujeitos assumem sobre este tipo peculiar de relatos, estas narrativas de si, na forma de postagens, indicam o modo como os sujeitos manejam a própria imagem, a própria palavra e a própria dor expressando-se e expondo-se diante dos outros em cenas nas quais subjetividade, experiência e política se interceptam.

\section{Referências bibliográficas}

BARENDT, Hannah. Sobre a revolução. Coleção Antropos. Trad. I. Morais. 1ª Edição. Lisboa: Relógio d'Água, 2001.

ARFUCH, Leonor. O espaço biográfico. Dilemas da subjetividade contemporânea. Rio de Janeiro: EDUERJ, 2010.

BOLTANSKI, Luc. Distant Suffering: morality, media and politics. Cambridge: Cambridge University Press, 1999.

BOLTANSKI, Luc; CHIAPELLO, Ève. O novo espirito do capitalismo. São Paulo: WMF Martins Fontes, 2013.

CERTEAU, Michel de. A invenção do cotidiano. Petrópolis: Vozes, 1998.

CHOULIARAKI, Lilie. The ironic spectator. Solidarity in the age of post-humanitarianism. Cambridge: Polity Press, 2013.

- Improper distance: towards a critical account of solidarity as irony. International Journal of Cultural Studies, 14 (4). 2011. pp. 363-381.

Post-humanitarianism: humanitarian communication beyond a politics of pity. International Journal of Cultural Studies, 13 (2). 2010. pp. 107-126. 
. The Spectatorship of Suffering. London: Sage, 2006.

DAS, Veena. $\mathrm{O}$ ato de testemunhar: violência, gênero e subjetividade. Trad. Plínio Dentzien. Cadernos Pagu, Campinas, n. 37, p. 9-41, jul./ dez. 2011.

Life and words: violence and the descent into the ordinary.

California: University of California Press, 2007.

DOUBROVSKY, Serge. Autobiografies: de Corneille à Sartre. Paris: PUF, 1977.

GUIMARÃES, César; FRANÇA, Vera. Experimentando as narrativas no cotidiano. In: Na Midia na Rua: narrativas do cotidiano. Belo Horizonte: Autêntica, 2006.

Experiência estética e vida ordinária. In: E-Compós, edição 1, dezembro de 2004.

LARUELLE, François. General theory of victmis. Cambridge: Polity Press, 2015.

LEAL, B; GUIMARÃES, C.; MENDONÇA, C. Entre o sensivel e o comunicacional. Belo Horizonte: Autêntica, 2010.

LEJEUNE, Philippe. O pacto autobiográfico. De Rousseau à Internet. Belo Horizonte: Editora UFMG, 2008.

JAGUARIBE, Beatriz. Realismo sujo e experiência autobiográfica. In: FATORELLI, Antonio: BRUNO, Fernanda (Orgs.). Limiares da imagem. Tecnologia e estética na cultura contemporânea. Rio de Janeiro: Mauad, 2006. pp.109-137.

SARTI, Chyntia. A vitima como figura contemporânea. Caderno CRH, Salvador, v.24, n.61, p. 51-61, jan. abril, 2011.

VAZ, Paulo; SANTOS, Amanda; ANDRADE, Pedro. Testemunho e subjetividade contemporânea: narrativas de vítimas de estupro e a construção social da inocência. Lumina. UFJF, v.8, n. 2, p.1-33, dez. 2014.

VAZ, Paulo; RONY, Gaëlle. Experiência urbana e narrativas de crime. E-compós, Brasília, vol.11, n.1, jan-abril 2008.

\section{Notas}

1. Pesquisa financiada pelo CNPq.

2. Nos exemplares trazidos notamos que as vítimas referenciam, indistintamente, nos seus relatos-postagens, tanto a dor de ordem física, inscrita no corpo pelas marcas das violências, muitas vezes, atestada pelos autorretratos postados, quanto o sofrimento, referente às afetaçóes internas e sensíveis, mais próprias à angústia e o padecimento de ordem subjetiva. Optamos por manter a observaçâo dos dois aspectos, conjuntamente, neste trabalho de descrição e investigação preliminar.

3. Utilizamos a expressão "relato biográfico", em uma dimensão mais ampla e geral que sua conceituação canônica, apenas para indicar a natureza destas novas formas narrativas acerca dos contínuos registros das vidas individuais que comparecem nas 
redes sociais. Não precisamos as diferenças classificatórias entre biografias, testemunhos, diários, ensaios ou outras formas de registros íntimos, mas nos atemos ao caráter mais geral destas formas de escritas de si que contemplam a vivencia cotidiana dos próprios sujeitos. Porém, uma designação conforme proposta por Leonor Arfuch (2010) nos parece importante e suficiente para nominar o material empírico com o qual lidamos, pois privilegia a centralidade do sujeito; a singularidade. Segundo ela, "a simples menção do biográfico remete, em primeira instância, a um universo de gêneros discursivos consagrados que tentam apreender a qualidade evanescente da vida opondo, à repetição cansativa dos dias, aos desfalecimentos da memória, o registro minucioso do acontecer, o relato das vicissitudes ou a nota fulgurante da vivência, capaz de iluminar o instante e a totalidade. Biografias, autobiografias, confissóes, memórias, diários íntimos, correspondências dão conta, há pouco mais de dois séculos, dessa obsessão por deixar impressōes, rastros, inscriçóes, dessa ênfase na singularidade, que é ao mesmo tempo busca de transcendência" (ARFUCH, 2010, 15).

4. Os conhecidos estudos de Philippe Lejeune, desde a década de 70, com a publicação dos célebres L'autobiographie en France (1971) e Le pacte biographie (1981), atribuíram nova atenção e importância a um gênero de escrita que antes era estigmatizado por uma suposta falta de autenticidade dentro do campo literário e das investigaçôes acadêmicas. Ao propor uma revisão sobre o tema autobiográfico na tentativa de teorizar a experiência íntima através de suas narrativas, Lejeune indica a necessidade de romper com a velha dicotomia que tanto hierarquizava a produção artístico literária, quanto defasava a compreensão cultural de uma época, através da manutenção de um modelo referencial da linguagem polarizado nas categorias real (em oposiçâo à mentira) e ficcional (em oposição à verdade). Ao diferenciar a autobiografia, os escritos íntimos, da historiografia e da ficcionalidade, Lejeune referencia outro estatuto às formas narrativas em seu enlace da linguagem e experiência. 